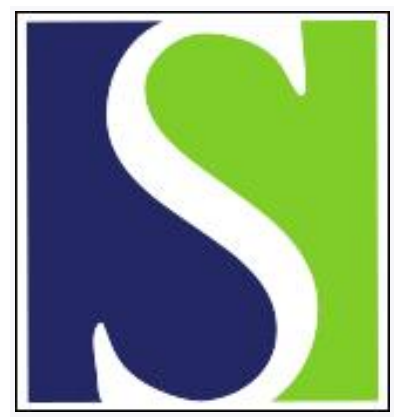

Scand J Work Environ Health 2013;39(5):448-455

https://doi.org/10.5271/sjweh.3360

Published online: 29 Mar 2013, Issue date: 01 Sep 2013

Night work and breast cancer estrogen receptor status results from the German GENICA study

by Rabstein S, Harth V, Pesch B, Pallapies D, Lotz A, Justenhoven C, Baisch C, Schiffermann M, Haas S, Fischer H-P, Heinze E, Pierl C, Brauch H, Hamann U, Ko Y, Brüning $T$

GENICA is a population-based case-control study on breast cancer with detailed information on shift work characteristics. We are the first to show the associations between night shift work and breast cancer with respect to estrogen receptor (ER) positive and negative tumors. Our results suggest a stronger association of chronobiological mechanisms with the development of ER-negative breast cancers.

Affiliation: Institute for Prevention and Occupational Medicine of the German Social Accident Insurance, Institute of the Ruhr-Universität Bochum (IPA), Bürkle-de-la-Camp-Platz 1, 44789 Bochum, Germany. rabstein@ipa-dguv.de

Refers to the following texts of the Journal: 2010;36(2):163-179 2010;36(2):134-141

The following articles refer to this text: 2014;40(3):295-304; 2017;43(1):59-67

Key terms: breast cancer; case-control study; circadian disruption; estrogen receptor; estrogen receptor status; GENICA; Germany; health; health; night work; occupation; shift work

This article in PubMed: www.ncbi.nlm.nih.gov/pubmed/23543199

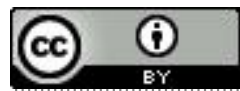




\title{
Night work and breast cancer estrogen receptor status - results from the German GENICA study
}

\author{
by Sylvia Rabstein, PhD, ${ }^{1,2}$ Volker Harth, PhD, 1, 2, 3 Beate Pesch, PhD, ${ }^{2}$ Dirk Pallapies, PhD, ${ }^{2}$ Anne Lotz, MSc, ${ }^{2}$ \\ Christina Justenhoven, PhD, ${ }^{4,5}$ Christian Baisch, MA, ${ }^{6}$ Markus Schiffermann, MD, ${ }^{6}$ Susanne Haas, PhD, ${ }^{7}$ \\ Hans-Peter Fischer, PhD, ${ }^{7}$ Evelyn Heinze, MA, ${ }^{2}$ Christiane Pierl, PhD, ${ }^{2}$ Hiltrud Brauch, PhD, ${ }^{4,5}$ Ute Hamann, \\ $P h D,{ }^{7}$ Yon Ko, PhD, ${ }^{8}$ Thomas Brüning, $P h D^{2}$ on behalf of the GENICA Consortium
}

Rabstein S, Harth V, Pesch B, Pallapies D, Lotz A, Justenhoven C, Baisch C, Schiffermann M, Haas S, Fischer H-P,
Heinze E, Pierl C, Brauch H, Hamann U, Ko Y, Brüning T. Night work and breast cancer estrogen receptor status -
results from the German GENICA study. Scand J Work Environ Health. 2013;39(5):448-455. doi:10.5271/sjweh.3360

Objectives The potential mechanisms that link night-shift work with breast cancer have been extensively discussed. Exposure to light at night (LAN) depletes melatonin that has oncostatic and anti-estrogenic properties and may lead to a modified expression of estrogen receptor (ER) $\alpha$. Here, we explored the association between shift work and breast cancer in subgroups of patients with ER-positive and -negative tumors.

Methods GENICA(Gene-ENvironment Interaction and breast CAncer) is a population-based case-control study on breast cancer with detailed information on shift work from 857 breast cancer cases and 892 controls. ER status was assessed by immunohistochemical staining. Associations between night-shift work and ER-positive and -negative breast cancer were analyzed with conditional logistic regression models, adjusted for potential confounders.

Results ER status was assessed for 827 cases and was positive in 653 and negative in 174 breast tumors. Overall, 49 cases and 54 controls were "ever employed" in shift work including night shifts for $\geq 1$ year. In total, "ever shift work" and "ever night work" were not associated with an elevated risk of ER-positive or -negative breast tumors. Night work for $\geq 20$ years was associated with a significantly elevated risk of ER-negative breast cancer [odds ratio (OR) 4.73, 95\% confidence interval (95\% CI) 1.22-18.36].

Conclusions Our case-control study suggests that long-term night-shift work is associated with an increased risk of ER-negative breast cancers. Further studies on histological subtypes and the analysis of other potentially relevant factors are crucial for discovering putative mechanisms.

Key terms case-control study; circadian disruption; Germany; health; occupation; shift work.

Shift work causes circadian disruption and was classified as "probably carcinogenic" (Group 2A) to humans by the International Agency for Research on Cancer (IARC) in 2007 (1). Approximately $25 \%$ of German employees are currently involved in schedules of shift work (2). Six percent of employed German women work in night shifts on a frequent basis (3). The putative mechanisms that link shift work and cancer have been extensively discussed for several cancer sites (4), in particular for breast cancer. With an estimated 1.4 million incident breast cancer cases worldwide in 2008 (5) and rising incidences in Western countries during the last decades, the hypothesis of light exposures during night (LAN) work influencing the circadian rhythm and the

1 Equally contributed.

2 Institute for Prevention and Occupational Medicine of the German Social Accident Insurance, Institute of the Ruhr-Universität Bochum (IPA), Bochum, Germany.

3 Institute for Occupational Medicine and Maritime Medicine, University Medical Centre Hamburg-Eppendorf, Germany.

4 Dr Margarete Fischer-Bosch-Institute of Clinical Pharmacology, Stuttgart, Germany

5 University of Tübingen, Tübingen, Germany.

6 Institute of Pathology, Medical Faculty of the University of Bonn, Bonn, Germany.

7 Molecular Genetics of Breast Cancer, Deutsches Krebsforschungszentrum (DKFZ), Heidelberg, Germany.

8 Department of Internal Medicine, Evangelische Kliniken Bonn gGmbH, Johanniter Krankenhaus, Bonn, Germany.

Correspondence to: Sylvia Rabstein, PhD, Institute for Prevention and Occupational Medicine of the German Social Accident Insurance, Institute of the Ruhr-Universität Bochum (IPA), Bürkle-de-la-Camp-Platz 1, 44789 Bochum, Germany. [E-mail: rabstein@ipa-dguv.de] 
hormonal balance has emerged as a relevant research topic $(6,7)$.

Under normal conditions without night work, the endogenous circadian pacemaker located in the suprachiasmatic nuclei (SCN) synchronizes circadian rhythms to the regular 24-hour light-dark cycle. The retinohypothalamic tract mediates information about the light-dark cycle. Via inhibitory neuronal activity, the SCN controls the production of the neurohormone and indoleamine melatonin (N-acetyl-5-methoxytryptamine). During the daytime, the pineal synthesis of melatonin is almost negligible (8).

Shift work as well as lifestyle may lead to altered sleep habits, sleep deprivation, and circadian disruption and is thought to interact with the circadian regulation of hormones that may be also relevant to cancer development. This is supported by the observational study of Flynn-Evans and colleagues (9) where blind women with no perception of light showed a reduced breast cancer risk compared to blind women with light perception. Garland and colleagues (10) hypothesized that lack of sunlight on the skin and consequent inadequate vitamin D production might be another carcinogenic mechanism. Furthermore, it has been argued that LAN also disrupts cortisol rhythms, which might also have an effect on breast cancer risk (11).

In animal models, exposure to LAN decreases the secretion of neurohormones such as melatonin (12). In cell lines and xenografts of human breast cancer, melatonin has antiproliferative properties that are probably mediated through a major mechanism involving the activation of the melatonin receptor MT1 (13). Melatonin is thought to inhibit the growth of human breast cancer xenografts via MT1-mediated suppression of cAMP leading to a blockade of linoleic acid uptake and its metabolism to the mitogenic signaling molecule 13-hydroxyoctadecadienoic acid (13-HODE). Other putative oncostatic mechanisms include antioxidant effects as a potent free radical scavenger, inhibition of telomerase activity, metastasis and angiogenesis, stimulation of cell differentiation, and activation of the immune system (14). In the avian hypothalamus, melatonin induces gonadotropin-inhibitory hormone $(\mathrm{GnIH})$, a neuropeptide that inhibits gonadotropin synthesis and release, as well as GnIH expression, thus inhibiting plasma LH concentrations and consequently influencing estrogen production (15).

Tamarkin and colleagues (16) suggested an inverse association between nocturnal melatonin levels and estrogen receptor (ER) expression in breast tumors. Melatonin is considered to be involved in the regulation of the ER expression (14). ER exerts various cellular functions and interacts with transcription factors (17). It has been suggested that ER has a carcinogenic effect by increasing the rate of cell divisions and therefore the number of random DNA mutations. Melatonin seems to inhibit the binding of the $\mathrm{E}_{2}$-ER complex to the estrogen response element in regulatory gene regions (18). Furthermore, melatonin down-regulates the hypothalamicpituitary reproductive axis and acts as a selective estrogen receptor modulator (SERM) and selective estrogen enzyme modulator (SEEM) via altered ER action on the tumor cell level.

The association between shift schedules, melatonin concentrations, and the development of breast cancer subtypes is part of ongoing studies. In the Nurses' Health Study (NHS), Schernhammer et al (19) found an inverse association between melatonin levels and breast cancer risk in postmenopausal women and in a subgroup analyses of women with ER-positive and -negative tumors.

To explore associations of night-shift work and ER status of breast tumors, we embarked on a more detailed analysis of the data of the GENICA (GeneENvironment Interaction and breast CAncer) study and extended the analyses from Pesch et al (20) to subgroups of ER status. We hypothesized that long duration of night-shift work promotes the risk of ERpositive breast tumors.

\section{Methods}

\section{Study population and breast cancer risk factors}

A population-based case-control study was conducted in the Greater Region of Bonn, Germany, as previously described (21). In brief, 1143 incident breast cancer cases and 1155 population controls were enrolled between 2000-2004 with response rates of $88 \%$ and $67 \%$, respectively. Cases were enrolled from the major hospitals of the region. Controls were ascertained as random sample from the population registries of the study region and frequency-matched to cases by age in 5 -year classes. Inclusion criteria comprised age $\leq 80$ years and being of European descent. Incident cases were women with histopathologically confirmed breast cancer diagnosed within six months before enrolment. Data on known and suspected risk factors, including a detailed occupational history, were obtained by in-person interviews (hereafter referred to as "core interview"). All participants gave written informed consent. The ethics committee of the University of Bonn approved GENICA.

In order to assess more detailed information on shift work and hormone replacement therapy (HRT) (22-24), subsequent telephone interviews were performed for 857 GENICA cases and 892 controls on hormone prescriptions between 2004-2007. In addition, shift work infor- 
mation was assessed for GENICA women, including having ever or never worked in shift or night work for $\geq 1$ year with the corresponding time frames. Among 247 GENICA women reporting shift work, 223 women (104 cases, 119 controls) could be reached for another telephone interview to collect detailed shift-work information for each occupational period (hereafter referred to as "shift interview"). Comprehensive plausibility checks were applied to assess night work and lifetime exposure to night shifts. Variables on shift and night-shift work were similar to those of our previously published study on shift work and breast cancer (20). Shift work was defined as ever having worked in shift work for $\geq 1$ year. Night work was defined as ever having worked in night shifts for $\geq 1$ year and working the fulltime period between 24:00-05:00 hours. Duration of shift work and other temporal information was truncated at the date of the core interview.

\section{Determination of receptor status}

For determination of ER expression, paraffin-embedded tissue specimens were stained immunohistochemically by a monoclonal nuclear antibody (25). Evaluation of receptor status followed the German Immuno Reactive Score as it is routinely used for evaluation of hormonal receptor expression for estrogen (26). The number of positive cells was multiplied by the intensity of nuclear staining. The following score levels were used: $0=0 \%$, $1=1-10 \%, 2=11-50 \%, 3=51-80 \%, 4=>80 \%$ positive cells and $0=$ negative, $1=$ weak, $2=$ moderate, $3=$ strong intensity of staining. The maximum score level was 12 for hormonal receptors corresponding to strong staining and $>80 \%$ positive cells. Score levels of $\geq 2$ were defined as positive expression. In addition, to enhance the number of subjects in subgroup analyses,receptor status was classified as positive or negative by reference pathology when either percentage or intensity of staining was missing in the dataset. In 30 cases, no information on ER status was available.

\section{Statistical analysis}

The association of night work with breast cancer was investigated with logistic regression models conditional on age (20-44, 45-49, 50-54, 55-59, 60-64, 65-69, $\geq 70$ years) among 857 breast cancer cases and 892 controls with information on shift status. The PHREG procedure in SAS software, version 9.2 (SAS Institute Inc, Cary, $\mathrm{NC}$, USA) was used to calculate risk estimates as OR with $95 \%$ CI.

The set of potential confounders comprised menopausal status (pre- or postmenopausal), education, breast cancer in mother or sister, parity (nulliparous, $1-2, \geq 3$ children), age at first birth (nulliparous, $<25,25-<30$, $\geq 30$ years), duration of oral contraceptive use and duration of menopausal HRT use (never, $>0-<10, \geq 10$ years), body-mass index (BMI) $(<22.5,22.5-<25,25-<30, \geq 30$ $\mathrm{kg} / \mathrm{m}^{2}$ ), smoking status (current, former, never), number of mammograms until two years before interview, and lifetime breastfeeding in months. Women were considered premenopausal if they reported bleedings in the year of interview and no bilateral oophorectomy. Education was categorized as low $=$ no occupational qualification and $\leq 8$ years at school, high=university degree, and medium $=$ other. For model building, night work was forced into the statistical model and potential confounder variables were added one at a time. Confounder variables were included in the final model if the respective risk estimate reached a significance level of $15 \%$. Confounder variables are family history of breast cancer, HRT use, and number of mammograms. Local $\mathrm{P}$-values $<0.05$ were declared as significant.

The reference group for shift work was defined as women employed in day work only. Never employed women were classified as a separate group. Risks were estimated for ever having done night work ("ever night work"), duration of night work, cumulative number of night shifts with and without the condition of $>3$ night shifts per month using the corresponding $3^{\text {rd }}$ quartile among controls as cut-off (807 and 1056 nightshifts, respectively). Subgroup analyses for cases with ERpositive and -negative tumors were performed.

\section{Results}

The distributions of risk factors for breast cancer are presented in table 1. Comparing receptor status, younger cases more often had ER-negative tumors (age $<50$ years: $35.1 \%$ versus $21.9 \%$ among controls), reflected also by a higher prevalence of premenopausal women. Use of HRT for $\geq 10$ years was associated with a higher prevalence of ER-positive tumors (30.1\% in ER-positive, $19.3 \%$ in ER-negative, and $20.8 \%$ in controls). A history of familial breast cancer was related to both positive and negative tumors (13.2\% and $12.1 \%$, respectively, versus $7.0 \%$ in controls). Other reproductive or lifestyle factors showed no significant differences among patients with ER-positive or -negative status.

Table 2 presents the distribution of potential risk factors for breast cancer by employment and shift status in the GENICA study population in relation to the ER status. Age-adjusted OR were calculated by logistic regression conditional on age, adjusted for family history of breast cancer, HRT, and number of mammograms. Women who were never employed were different in age, lifestyle and reproductive factors (data not shown). Therefore, we chose "employed women" and "employed 
Table 1. Potential breast cancer risk factors in participants of the GENICA study. [ER=estrogen receptor]

\begin{tabular}{|c|c|c|c|c|c|c|c|c|c|c|}
\hline \multirow[t]{2}{*}{ Factor $^{a}$} & \multicolumn{2}{|c|}{$\begin{array}{l}\text { All cases } \\
(\mathrm{N}=857)\end{array}$} & \multicolumn{2}{|c|}{$\begin{array}{l}\text { ER-positive cases } \\
\qquad(\mathrm{N}=653)\end{array}$} & \multicolumn{2}{|c|}{$\begin{array}{l}\text { ER-negative } \\
\text { cases }(N=174)\end{array}$} & \multicolumn{2}{|c|}{$\begin{array}{l}\text { ER-missing } \\
\text { cases }(N=30)\end{array}$} & \multicolumn{2}{|c|}{$\begin{array}{l}\text { Controls } \\
(\mathrm{N}=892)\end{array}$} \\
\hline & $\mathrm{N}$ & $\%$ & $\mathrm{~N}$ & $\%$ & $\mathrm{~N}$ & $\%$ & $\mathrm{~N}$ & $\%$ & $\mathrm{~N}$ & $\%$ \\
\hline \multicolumn{11}{|l|}{ Age (years) } \\
\hline$<50$ & 199 & 23.2 & 132 & 20.2 & 61 & 35.1 & 6 & 20.0 & 195 & 21.9 \\
\hline $50-<60$ & 268 & 31.3 & 203 & 31.1 & 56 & 32.2 & 9 & 30.0 & 276 & 30.9 \\
\hline $60-<70$ & 288 & 33.6 & 239 & 36.6 & 41 & 23.6 & 8 & 26.7 & 304 & 34.1 \\
\hline $70-80$ & 102 & 11.9 & 79 & 12.1 & 16 & 9.2 & 7 & 23.3 & 117 & 13.1 \\
\hline \multicolumn{11}{|c|}{ Menopausal status } \\
\hline Pre & 218 & 25.8 & 148 & 23.0 & 62 & 35.8 & 8 & 28.6 & 207 & 23.5 \\
\hline Post & 627 & 74.2 & 496 & 77.0 & 111 & 64.2 & 20 & 71.4 & 673 & 76.5 \\
\hline \multicolumn{11}{|l|}{ Education b } \\
\hline High & 116 & 13.5 & 90 & 13.8 & 24 & 13.8 & 8 & 26.7 & 142 & 15.9 \\
\hline Median & 634 & 74.0 & 480 & 73.5 & 134 & 77.0 & 20 & 66.7 & 642 & 72.0 \\
\hline Low & 107 & 12.5 & 83 & 12.7 & 16 & 9.2 & 2 & 6.7 & 108 & 12.1 \\
\hline \multicolumn{11}{|l|}{ Parity } \\
\hline Nulliparous & 147 & 17.2 & 108 & 16.5 & 34 & 19.5 & 5 & 16.7 & 157 & 17.6 \\
\hline 1-2 children & 527 & 61.5 & 398 & 61.0 & 115 & 66.1 & 14 & 46.7 & 538 & 60.4 \\
\hline$\geq 3$ children & 183 & 21.4 & 147 & 22.5 & 25 & 14.4 & 11 & 36.7 & 196 & 22.0 \\
\hline \multicolumn{11}{|c|}{ Age at first birth (years) } \\
\hline Nulliparous & 147 & 17.2 & 108 & 16.6 & 34 & 19.5 & 5 & 16.7 & 157 & 17.6 \\
\hline$<25$ & 341 & 39.8 & 254 & 39.0 & 73 & 42.0 & 14 & 46.7 & 360 & 40.4 \\
\hline $25-<30$ & 241 & 28.2 & 189 & 29.0 & 43 & 24.7 & 9 & 30.0 & 253 & 28.4 \\
\hline$\geq 30$ & 127 & 14.8 & 101 & 15.5 & 24 & 13.8 & 2 & 6.7 & 121 & 13.6 \\
\hline \multicolumn{11}{|c|}{ Oral contraceptive use (years) } \\
\hline Never & 274 & 32.1 & 219 & 33.6 & 46 & 26.6 & 9 & 30.0 & 291 & 32.7 \\
\hline $1-<10$ & 283 & 33.1 & 218 & 33.4 & 59 & 34.1 & 6 & 20.0 & 280 & 31.5 \\
\hline$\geq 10$ & 298 & 34.9 & 215 & 33.0 & 68 & 39.1 & 15 & 50.0 & 319 & 35.8 \\
\hline \multicolumn{11}{|c|}{ Hormone replacement therapy (years) } \\
\hline Never & 415 & 48.7 & 299 & 45.9 & 101 & 59.1 & 15 & 50.0 & 445 & 50.0 \\
\hline$>0-<10$ & 203 & 23.8 & 157 & 24.1 & 37 & 21.6 & 9 & 30.0 & 260 & 29.2 \\
\hline$\geq 10$ & 235 & 27.6 & 196 & 30.1 & 33 & 19.3 & 6 & 20.0 & 185 & 20.8 \\
\hline \multicolumn{11}{|c|}{ Packyears (years) } \\
\hline 0 & 483 & 60.4 & 384 & 63.1 & 82 & 50.6 & 17 & 58.6 & 487 & 58.6 \\
\hline$>0-<15$ & 155 & 19.4 & 110 & 18.1 & 41 & 25.3 & 4 & 13.8 & 171 & 20.6 \\
\hline$\geq 15$ & 162 & 20.3 & 115 & 18.9 & 39 & 24.1 & 8 & 27.6 & 173 & 20.8 \\
\hline \multicolumn{11}{|c|}{ Body-mass index $\left(\mathrm{kg} / \mathrm{m}^{2}\right)$} \\
\hline$<22.5$ & 266 & 31.0 & 209 & 32.0 & 54 & 31.0 & 3 & 10.0 & 274 & 30.8 \\
\hline $22.5-<25$ & 218 & 25.4 & 162 & 24.8 & 45 & 25.9 & 11 & 36.7 & 216 & 24.2 \\
\hline $25-<30$ & 246 & 28.7 & 192 & 29.4 & 46 & 26.4 & 8 & 26.7 & 269 & 30.2 \\
\hline$\geq 30$ & 127 & 14.8 & 90 & 13.8 & 29 & 16.7 & 8 & 26.7 & 132 & 14.8 \\
\hline \multicolumn{11}{|c|}{ Breast cancer in mother or sisters } \\
\hline No & 747 & 87.2 & 567 & 86.8 & 153 & 87.9 & 27 & 90.0 & 830 & 93.1 \\
\hline Yes & 110 & 12.8 & 86 & 13.2 & 21 & 12.1 & 3 & 10.0 & 62 & 7.0 \\
\hline \multicolumn{11}{|c|}{ Number of mammograms ${ }^{c}$} \\
\hline None & 120 & 14.0 & 80 & 12.3 & 37 & 21.4 & 3 & 10.0 & 134 & 15.0 \\
\hline $1-<10$ & 551 & 64.4 & 425 & 63.2 & 108 & 62.4 & 18 & 60.0 & 599 & 67.2 \\
\hline$\geq 10$ & 184 & 21.5 & 147 & 22.6 & 28 & 16.2 & 9 & 30.0 & 158 & 17.7 \\
\hline
\end{tabular}

a Sums may differ because of missing values.

b Low education if no occupational qualification and $\leq 8$ years at school, high education if university degree, otherwise categorized as medium.

c Lifetime number of diagnostic mammograms until two years before interview.

women without shift work" as reference groups. When using employed women as a reference, never employed women showed an elevated risk estimate for ER-positive breast cancer (OR 1.72, 95\% CI 1.02-2.92). Ever shift or night-shift work was not associated with a significant increase in risk for ER-positive or -negative breast cancer when compared to women "employed, but never in shift work" (OR 0.98, 95\% 0.63-1.50 and OR 1.16, 95\% $0.62-2.18$, respectively).

Results for night-shift workers with respect to ER-positive and -negative subgroups are presented in table 3. Breast cancer patients had worked more night shifts during their lifetime than controls (median 791, interquartile range (IQR) 360-1440, versus median 318, IQR 180-807). A high cumulative number of night shifts ( $>806$ lifetime night shifts or $>1055$ lifetime night shifts for shift systems with $>3$ nights per month) was associated with an increased, but statistically not significant risk for ER-negative tumors (OR 2.34, 95\% CI $0.89-6.14$ and OR 2.11, 95\% CI 0.76-5.90, respectively). Also, night-shift work for $\geq 20$ years resulted in an OR of 4.73 (95\% CI 1.22-18.36) for ER-negative breast cancer (based on 5 controls and 4 ER-negative cases). 
Table 2. Association of employment status and breast cancer in the GENICA study. [ER=estrogen receptor; $0 \mathrm{R}=0 \mathrm{dds}$ ratio; $95 \% \mathrm{Cl}=95 \%$ confidence interval]

\begin{tabular}{|c|c|c|c|c|c|c|c|c|c|c|c|c|c|c|}
\hline \multirow[t]{2}{*}{ Factor ${ }^{a}$} & \multicolumn{2}{|c|}{$\begin{array}{l}\text { Controls } \\
(\mathrm{N}=892)\end{array}$} & \multicolumn{4}{|c|}{$\begin{array}{l}\text { Cases } \\
(\mathrm{N}=857)\end{array}$} & \multicolumn{4}{|c|}{$\begin{array}{l}\text { ER-positive cases } \\
(\mathrm{N}=653)\end{array}$} & \multicolumn{4}{|c|}{$\begin{array}{c}\text { ER-negative } \\
\text { cases }(N=174)\end{array}$} \\
\hline & $\mathrm{N}$ & $\%$ & $\mathrm{~N}$ & $\%$ & $\mathrm{OR}^{\mathrm{b}}$ & $95 \% \mathrm{Cl}$ & $\mathrm{N}$ & $\%$ & $\mathrm{OR}^{\mathrm{b}}$ & $95 \% \mathrm{Cl}$ & $\mathrm{N}$ & $\%$ & $\mathrm{OR}^{\mathrm{b}}$ & $95 \% \mathrm{Cl}$ \\
\hline \multicolumn{15}{|l|}{ Current or last occupation } \\
\hline Employee & 699 & 78.6 & 647 & 76.1 & 1 & & 496 & 76.3 & 1 & & 136 & 79.0 & 1 & \\
\hline Worker & 71 & 8.0 & 69 & 8.1 & 1.12 & $0.78-1.59$ & 52 & 8.0 & 1.07 & $0.73-1.57$ & 11 & 8.3 & 0.97 & $0.50-1.91$ \\
\hline Others ${ }^{c}$ & 89 & 10.0 & 94 & 11.1 & 1.23 & $0.89-1.68$ & 68 & 10.5 & 1.15 & $0.82-1.62$ & 19 & 10.5 & 1.27 & $0.74-2.18$ \\
\hline Never employed & 30 & 3.4 & 40 & 4.7 & 1.60 & $0.97-2.66$ & 34 & 5.2 & 1.72 & $1.02-2.92$ & 4 & 2.3 & 0.93 & $0.31-2.77$ \\
\hline \multicolumn{15}{|l|}{ Shift work } \\
\hline Employed, but never in shift work & 740 & 83.2 & 698 & 82.1 & 1 & & 539 & 82.9 & 1 & & 134 & 78.8 & 1 & \\
\hline Ever in shift work & 119 & 13.4 & 112 & 13.2 & 0.98 & $0.74-1.29$ & 77 & 11.9 & 0.89 & $0.65-1.22$ & 32 & 18.8 & 1.36 & $0.87-2.11$ \\
\hline Never employed & 30 & 3.4 & 40 & 4.7 & 1.54 & $0.93-2.54$ & 34 & 5.2 & 1.66 & $0.98-2.80$ & 4 & 2.4 & 0.95 & $0.32-2.83$ \\
\hline \multicolumn{15}{|l|}{ Night-shift work } \\
\hline Employed, but never in shift work & 740 & 92.7 & 689 & 92.7 & 1 & & 539 & 93.3 & 1 & & 134 & 90.5 & 1 & \\
\hline Ever in night-shift work & 56 & 7.0 & 55 & 7.3 & 1.01 & $0.68-1.50$ & 39 & 6.8 & 0.98 & $0.63-1.50$ & 14 & 9.5 & 1.16 & $0.62-2.18$ \\
\hline
\end{tabular}

a Numbers may differ because of missing values in ER status and confounders.

${ }^{\mathrm{b}}$ Logistic regression conditional on age, adjusted for family history of breast cancer, hormone replacement use, and number of mammograms.

${ }^{c}$ Other employment included self-employed women, women helping the partner in business, and women in educational programs.

Table 3. Association of shift characteristics and breast cancer in GENICA women with detailed shift-work information. [ER=estrogen receptor; OR=odds ratio; $95 \% \mathrm{Cl}=95 \%$ confidence interval]

\begin{tabular}{|c|c|c|c|c|c|c|c|c|c|c|c|c|c|c|}
\hline \multirow[t]{2}{*}{ Factor ${ }^{a}$} & \multicolumn{2}{|c|}{ Controls ${ }^{b}$} & \multicolumn{4}{|c|}{ Cases $^{b}$} & \multicolumn{4}{|c|}{ ER-positive cases ${ }^{b}$} & \multicolumn{4}{|c|}{ ER-negative cases ${ }^{b}$} \\
\hline & $\mathrm{N}$ & $\%$ & $\mathrm{~N}$ & $\%$ & $\mathrm{OR}^{\mathrm{c}}$ & $95 \% \mathrm{Cl}$ & $\mathrm{N}$ & $\%$ & $\mathrm{OR}_{\mathrm{adj}}{ }^{\mathrm{c}}$ & $95 \% \mathrm{Cl}$ & $\mathrm{N}$ & $\%$ & $O R_{a d j}{ }^{c}$ & $95 \% \mathrm{Cl}$ \\
\hline \multicolumn{15}{|l|}{$\begin{array}{l}\text { Cumulative number of lifetime night } \\
\text { shifts }\end{array}$} \\
\hline Employed, but never in shift work & 740 & 93.3 & 698 & 93.6 & 1 & & 539 & 94.2 & 1 & & 134 & 91.2 & 1 & \\
\hline$<807$ night shifts & 40 & 5.0 & 25 & 3.4 & 0.66 & $0.39-1.11$ & 18 & 3.2 & 0.66 & $0.37-1.16$ & 6 & 4.1 & 0.71 & $0.29-1.75$ \\
\hline$\geq 807$ night shift & 13 & 1.6 & 23 & 3.1 & 1.78 & $0.89-3.58$ & 15 & 2.6 & 1.56 & $0.73-3.33$ & 7 & 4.8 & 2.34 & $0.89-6.14$ \\
\hline \multicolumn{15}{|l|}{$\begin{array}{l}\text { Cumulative number of lifetime night } \\
\text { shifts for shift systems with more } \\
\text { than three nights per month }\end{array}$} \\
\hline Employed, but never in shift work & 740 & 94.3 & 698 & 93.9 & 1 & & 539 & 94.7 & 1 & & 134 & 91.2 & 1 & \\
\hline$<1056$ night shifts & 33 & 4.2 & 25 & 3.4 & 0.80 & $0.47-1.36$ & 17 & 3.0 & 0.74 & $0.41-1.36$ & 7 & 4.8 & 1.02 & $0.44-2.40$ \\
\hline$\geq 1056$ night shifts & 12 & 1.5 & 20 & 2.7 & 1.66 & $0.80-3.46$ & 13 & 2.3 & 1.46 & $0.65-3.28$ & 6 & 4.1 & 2.11 & $0.76-5.90$ \\
\hline \multicolumn{15}{|l|}{ Duration of night-shift work (years) } \\
\hline Employed, but never in shift work & 740 & 93.3 & 698 & 93.6 & 1 & & 541 & 94.3 & 1 & & 134 & 91.2 & 1 & \\
\hline$>1-<5$ & 25 & 3.2 & 15 & 2.0 & 0.64 & $0.34-1.24$ & 10 & 1.7 & 0.58 & $0.27-1.22$ & 4 & 2.7 & 0.89 & $0.30-2.64$ \\
\hline $5-<10$ & 12 & 1.5 & 11 & 1.5 & 0.93 & $0.41-2.15$ & 8 & 1.4 & 0.96 & $0.39-2.40$ & 3 & 2.0 & 0.98 & $0.26-3.64$ \\
\hline $10-<20$ & 11 & 1.4 & 10 & 1.3 & 0.91 & $0.38-2.18$ & 8 & 1.4 & 1.04 & $0.41-2.64$ & 2 & 2.0 & 0.58 & $0.1--2.72$ \\
\hline$\geq 20$ & 5 & 0.6 & 12 & 1.6 & 2.49 & $0.87-7.18$ & 7 & 1.2 & 1.81 & $0.56-5.83$ & 4 & 2.7 & 4.73 & $1.22-18.36$ \\
\hline
\end{tabular}

a Numbers may differ because of missing values in ER status and confounders.

${ }^{b}$ Numbers refer to employed women that never worked in shift work and women with night-shift work.

${ }^{c}$ Logistic regression conditional on age, adjusted for family history of breast cancer, hormone replacement use and number of mammograms.

\section{Discussion}

In this study, we assessed the effects of night work in subgroups of patients with ER-positive and -negative breast tumors. Our results suggest that the role of chronobiological mechanisms might be more relevant to the development of ER-negative breast cancers. Workrelated subgroup analysis showed that women working night shifts for $\geq 20$ years were associated with a statistically significant 4.7-fold increased risk of ER-negative breast cancer and non-significant 1.8-fold increased risk of ER-positive breast cancer.

Due to the IARC classification (1), the possible health effects of shift work in relation to the development of breast cancer have become a particular public health concern. Until now, many possible mechanisms for cancer development have been discussed, of which a prominent one is the misalignment of circadian rhythms possibly caused by artificial LAN and sleep disruption. As one hypothesis for general tumorigenesis, regulatory rhythms such as the nocturnal production and blood concentrations of the neurohormone melatonin are disturbed, which might influence other hormones (27).

Breast cancer is a heterogeneous disease with regard to different clinical, pathologic, and molecular characteristics and etiology. Stratified analyses by hormone receptor subgroups may reveal associations that 
may otherwise be masked (28). The occurrence of ERpositive breast tumors correlates with increasing age. Tumors that lack expression of the ER are associated with more aggressive disease, higher histological grade, and poor survival rates (29). ER-positive compared to -negative tumors exhibit better clinical responses to endocrine treatment like SERM leading to a better prognosis and a longer survival of cancer patients.

In our case-control study, compared to ER-positive breast cancer, ER-negative breast cancer had a stronger association with long-term night-shift work. In 2001, Schernhammer et al (30) found a moderate increase in risks for ER-positive cancer after longer duration in rotating night shifts. The risk of ER-negative breast tumors was not elevated. The NHS and GENICA differ with respect to some characteristics of the study population, in particular menopausal status. In the NHS, a relatively low number of premenopausal cases were analyzed with respect to shift work (218 premenopausal women in GENICA and 309 premenopausal women in NHS). In addition, cut-off points for the categories of long duration of night-shift work differed. In the NHS, long duration of night-shift work was defined as working night shifts $\geq 30$ years. For premenopausal women, the highest category was defined as a duration of $\geq 15$ years. In GENICA, the analyses of duration of nightshift work were more detailed for $<20$ years of nightshift work. The cut-off point for the highest exposure category was 20 years. In addition, GENICA women with ER-negative tumors were younger than women with ER-positive tumors. The timing of night-shift work was also addressed in Menegaux et al's recent case-control study (31). However, they did not find an association of shift work with ER tumor subgroups. As a limitation, animal and in vitro studies have provided a large number of putative biological mechanisms, but epidemiological studies have even failed to demonstrate whether specific shift schedules may cause continuous reductions in melatonin concentrations, which then lead to raised estrogen levels favoring the development of breast cancer. Therefore, the undergoing populationbased large-scale studies should consider the putative influence of lifestyle and shift work on molecular characteristics of breast cancer.

The MT1-mediated anti-proliferative effects of the neurohormone melatonin signal are crucial for cancer prevention by endogen melatonin levels produced during the dark period. Zhu and colleagues (32) discussed the existence of two independent pathways of tumorigenesis to explain the origin of ER-positive and -negative tumors, but independently the carcinogenic effects of melatonin depletion seem to affect both cancer pathways. The additional anti-estrogenic effect of melatonin might imply a higher preventive effect on the cancer development of ER-positive breast tumors. The predominant role of MT1-mediated effects might be one explanation for the higher prevalence of ER-negative tumors among night-shift workers as found in our study. Recently, the role of core circadian genes in breast tumorigenesis has been extensively discussed. Circadian genes may function as oncogenes or tumor suppressors at the systemic, cellular, and molecular levels due to their involvement in cell proliferation, apoptosis, cell cycle control, and DNA damage response (33). Surprisingly, Hoffman and colleagues (34), who analyzed single nucleotide polymorphisms of the CLOCK gene and status of ER and progesterone receptor (PR), observed the strongest associations between variations of the CLOCK gene and breast cancer risk within the group of ER/PR-negative tumors (34). Moreover, CLOCK gene expression was significantly higher in tissue extracted from patients with ER/PR-negative tumors relative to those with ER/PR-positive cancers suggesting that chronobiological mechanisms might be even more relevant in ER/PR-negative breast cancers.

Postmenopausal women are underrepresented in our study, and - in subgroup-analysis - long-term shift working breast cancer patients were on average 53 years of age (data not shown). ER-negative cases were younger and more often younger at the time of first night shift. The frequency of women who started working in night shift when they were $<20$ years was much higher in ER-negative than ER-positive cases (38.4\% versus $27.3 \%$, data not shown). However, controls had an even higher frequency of women with first night shifts at $<20$ years of age (52.8\%, data not shown). The women with ER-negative tumors and $\geq 20$ years of night shift were all postmenopausal but $<60$ years old. Further analysis of potential confounders showed that women working night shifts differed from the reference group regarding reproductive and hormonal factors (data not shown). They were more frequently nulliparous, and younger, and HRT use was less common, which might favor breast cancers with a tendency for ER-negative status, as recently published (35). However, our results were similar when comparing statistical models including only age with models additionally adjusting for hormonal and other factors, or full models, and consecutively do not provide evidence for potential confounding.

Although the risk estimates for long duration of night-shift work were based on only 11 cases and 5 controls, they were robust with regard to adjustment for potential confounders. Additionally, we found that never employed women showed a statistically significant 1.7fold risk for ER-positive breast cancer when compared to employed women. However, it is well known that never employed women differ from the general working population in lifestyle behavior and many reproductive (eg, more frequent and earlier births) and hormonal factors. These factors might favor the increased risk for ER- 
positive breast tumors (36) although statistical analysis was conditional on age and adjusted for family history of breast cancer, HRT and number of mammograms. However, all never employed women in our study were postmenopausal (data not shown), a status when ERpositive breast cancers are more likely to be prevalent.

Due to the low prevalence of especially long-term night-shift work in the general population, the study had limited power for the assessment of an association between night-shift work and ER status in breast cancer cases. Another weakness is the analysis of subgroups of ER status that adds to the small numbers in exposure categories. However, ER status could be reliably assessed in almost all cases. Exposure misclassification is a potential source for bias. We performed comprehensive plausibility checks comparing the details of occupational history with the shift work information in the subsequent interviews. A particular strength of this study is the detailed exposure assessment not only for shift work, but also for various potential occupational and non-occupational confounders. Our study supports the relevance of further mechanistic research addressing the interaction of circadian disruption with sex hormone levels and related receptors.

In conclusion, our results confirm the potential role of night-shift work in breast cancer development. Shift work may affect carcinogenesis and could favor ER-negative tumors. Further studies on histological subtypes and the analysis of other potentially relevant factors, such as sleep quality or light-exposure, are crucial for discovering putative mechanisms.

\section{Acknowledgments}

This work was supported by the German Federal Ministry of Education and Research (BMBF) grants 01KW9975/5, 01KW9976/8, 01KW9977/0, 01KW0114, and $01 \mathrm{KH} 0411$, the Institute for Prevention and Occupational Medicine of the German Social Accident Insurance, Ruhr-University Bochum (IPA), the Robert Bosch Foundation, Stuttgart, EvangelischeKliniken Bonn GmbH, and Deutsches Krebsforschungszentrum, Heidelberg, Germany.

\section{References}

1. Straif K, Bouvard V, Altieri A, Benbrahim-Tallaa L, Cogliano V, and on behalf of the WHO International Agency for Research on Cancer Monograph Working Group. Carcinogenicity of shift-work, painting, and fire-fighting. The Lancet Oncology. 2007;8:1065-6. http://dx.doi.org/10.1016/ S1470-2045(07)70373-X.
2. Siefer A, Beermann B. Grundauswertung der BIBB/BAuAErwerbstätigenbefragung 2005/2006. mit den Schwerpunkten Arbeitsbedingungen, Arbeitsbelastungen und gesundheitliche Beschwerden [Baseline Analysis of BIBB/BAuA-employees survey 2005/2006 on working conditions, work strain and implications for health.] Dortmund/Berlin/Dresden: Bundesanstalt für Arbeitsschutz und Arbeitsmedizin; 2010.

3. Federal Statistical Office of Germany. Frauen und Männer auf dem Arbeitsmarkt - Deutschland und Europa [Women and men in the labour market - Germany and Europe]. Wiesbaden, Germany; 2012. Available from: https://www.destatis.de/DE/ Publikationen/Thematisch/Arbeitsmarkt/Erwerbstaetige/ BroeschuereFrauenMaennerArbeitsmarkt.html .

4. Costa G, Haus E, Stevens R. Shift work and cancer considerations on rationale, mechanisms, and epidemiology. Scand J Work Environ Health. 2010;36:163-79. http://dx.doi. org/10.5271/sjweh.2899.

5. Ferlay J, Shin HR, Bray F, Forman D, Mathers C, Parkin DM. Estimates of worldwide burden of cancer in 2008: GLOBOCAN 2008. Int J Cancer. 2010;127:2893-917. http:// dx.doi.org/10.1002/ijc.25516.

6. Hansen J, Stevens RG. Case-control study of shift-work and breast cancer risk in Danish nurses: Impact of shift systems. Eur J Cancer. 2012;48(11):1722-9. http://dx.doi. org/10.1016/j.ejca.2011.07.005.

7. Stevens RG. Light-at-night, circadian disruption and breast cancer: assessment of existing evidence. Int $\mathrm{J}$ Epidemiol. 2009;38:963-70. http://dx.doi.org/10.1093/ije/dyp178.

8. Claustrat B, Brun J, Chazot G. The basic physiology and pathophysiology of melatonin. Sleep Med Rev. 2005;9:11-24. http://dx.doi.org/10.1016/j.smrv.2004.08.001.

9. Flynn-Evans EE, Stevens RG, Tabandeh H, Schernhammer ES, Lockley SW. Total visual blindness is protective against breast cancer. Cancer Causes Control. 2009;20:1753-6. http:// dx.doi.org/10.1007/s10552-009-9405-0.

10. Garland CF, Garland FC, Gorham ED, Lipkin M, Newmark H, Mohr SB, et al. The role of vitamin D in cancer prevention. Am J Public Health. 2006;96:252-61. http://dx.doi.org/10.2105/ AJPH.2004.045260.

11. Sephton S, Spiegel D. Circadian disruption in cancer: a neuroendocrine-immune pathway from stress to disease? Brain Behav Immun. 2003;17:321-8. http://dx.doi.org/10.1016/ S0889-1591(03)00078-3.

12. Blask DE, Brainard GC, Dauchy RT, Hanifin JP, Davidson LK, Krause JA, et al. Melatonin-depleted blood from premenopausal women exposed to light at night stimulates growth of human breast cancer xenografts in nude rats. Cancer Res. 2005;65:11174-84. http://dx.doi.org/10.1158/00085472.CAN-05-1945.

13. Blask DE, Hill SM, Dauchy RT, Xiang S, Yuan L, Duplessis T, et al. Circadian regulation of molecular, dietary, and metabolic signaling mechanisms of human breast cancer growth by the nocturnal melatonin signal and the consequences of its disruption by light at night. J Pineal Res. 2011;51:259-69. http://dx.doi.org/10.1111/j.1600-079X.2011.00888.x. 
14. Mediavilla MD, Sanchez-Barcelo EJ, Tan DX, Manchester $\mathrm{L}$, Reiter RJ. Basic mechanisms involved in the anti-cancer effects of melatonin. Curr Med Chem. 2010;17:4462-81. http://dx.doi.org/10.2174/092986710794183015.

15. Chowdhury VS, Yamamoto K, Ubuka T, Bentley GE, Hattori A, Tsutsui K. Melatonin stimulates the release of gonadotropin-inhibitory hormone by the avian hypothalamus. Endocrinology. 2010;151:271-80. http://dx.doi.org/10.1210/ en.2009-0908.

16. Tamarkin L, Danforth D, Lichter A, DeMoss E, Cohen M, Chabner B, et al. Decreased nocturnal plasma melatonin peak in patients with estrogen receptor positive breast cancer. Science. 1982;216:1003-5. http://dx.doi.org/10.1126/ science. 7079745 .

17. Thomas C, Gustafsson JA. The different roles of ER subtypes in cancer biology and therapy. Nat Rev Cancer. 2011;11:597608. http://dx.doi.org/10.1038/nrc3093.

18. Sanchez-Barcelo EJ, Cos S, Mediavilla D, Martinez-Campa C, Gonzalez A, Alonso-Gonzalez C. Melatonin-estrogen interactions in breast cancer. J Pineal Res. 2005;38:217-22. http://dx.doi.org/10.1111/j.1600-079X.2004.00207.x.

19. Schernhammer ES, Hankinson SE. Urinary melatonin levels and postmenopausal breast cancer risk in the Nurses Health Study cohort. Cancer Epidemiol Biomarkers Prev. 2009;18:74-9. http://dx.doi.org/10.1158/1055-9965.EPI-080637.

20. Pesch B, Ko Y, Brauch H, Hamann U, Harth V, Rabstein S, et al. Factors modifying the association between hormonereplacement therapy and breast cancer risk. Eur J Epidemiol. 2005;20(8):699-711. http://dx.doi.org/10.1007/s10654-0050032-0.

21. Pesch B, Harth V, Rabstein S, Baisch C, Schiffermann M, Pallapies D, et al. Night work and breast cancer - results from the German GENICA study. Scand J Work Environ Health. 2010;36:134-41. http://dx.doi.org/10.5271/sjweh.2890.

22. Flesch-Janys D, Slanger T, Mutschelknauss E, Kropp S, Obi $\mathrm{N}$, Vettorazzi E, et al. Risk of different histological types of postmenopausal breast cancer by type and regimen of menopausal hormone therapy. Int J Cancer. 2008;123:933-41. http://dx.doi.org/10.1002/ijc.23655.

23. Kropp S, Terboven T, Hedicke J, Mutschelknauss E, Slanger $\mathrm{T}$, Braendle W, et al. Good agreement between physician and self-reported hormone therapy data in a case-control study. J Clin Epidemiol. 2007;60:1280-7. http://dx.doi.org/10.1016/j. jclinepi.2007.02.013.

24. Schmidt ME, Steindorf K, Mutschelknauss E, Slanger T, Kropp S, Obi N, et al. Physical activity and postmenopausal breast cancer: effect modification by breast cancer subtypes and effective periods in life. Cancer Epidemiol Biomarkers Prev. 2008;17:3402-10. http://dx.doi.org/10.1158/10559965.EPI-08-0479.

25. Haas S, Pierl C, Harth V, Pesch B, Rabstein S, Bruning T, et al. Expression of xenobiotic and steroid hormone metabolizing enzymes in human breast carcinomas. Int $\mathrm{J}$ Cancer. 2006;119:1785-91. http://dx.doi.org/10.1002/ijc.21915.

26. Remmele W, Stegner HE. Recommendation for uniform definition of an immunoreactive score (IRS) for immunohistochemical estrogen receptor detection (ER-ICA) in breast cancer tissue. Pathologe. 1987;8:138-40.

27. Haus E, Smolensky M. Biological clocks and shift work: circadian dysregulation and potential long-term effects. Cancer Causes Control. 2006;17:489-500. http://dx.doi.org/10.1007/ s10552-005-9015-4.

28. Althuis MD, Fergenbaum JH, Garcia-Closas M, Brinton LA, Madigan MP, Sherman ME. Etiology of hormone receptordefined breast cancer: a systematic review of the literature. Cancer Epidemiol Biomarkers Prev. 2004;13:1558-68.

29. Parl FF, Schmidt BP, Dupont WD, Wagner RK. Prognostic significance of estrogen receptor status in breast cancer in relation to tumor stage, axillary node metastasis, and histopathologic grading. Cancer. 1984;54:2237-42. http://dx.doi. org/10.1002/1097-0142(19841115)54:10<2237::AIDCNCR2820541029>3.0.CO;2-V.

30. Schernhammer ES, Laden F, Speizer FE, Willett WC, Hunter DJ, Kawachi I, et al. Rotating night shifts and risk of breast cancer in women participating in the Nurses' Health Study. J Natl Cancer Inst. 2001;93:1563-8. http://dx.doi.org/10.1093/ jnci/93.20.1563.

31. Menegaux F, Truong T, Anger A, Cordina-Duverger E, Lamkarkach F, Arveux P, et al. Night work and breast cancer: A population-based case-control study in France (the CECILE study). Int J Cancer. 2013 Feb 15;132(4):924-31. http:// dx.doi.org/10.1002/ijc.27669.

32. Zhu K, Bernard LJ, Levine RS, Williams SM. Estrogen receptor status of breast cancer: a marker of different stages of tumor or different entities of the disease? Med Hypotheses. 1997;49:69-75. http://dx.doi.org/10.1016/ S0306-9877(97)90255-3.

33. Fu LN, Lee CC. The circadian clock: Pacemaker and tumour suppressor. Nature Reviews Cancer. 2003;3:350-61. http:// dx.doi.org/10.1038/nrc1072.

34. Hoffman AE, Yi CH, Zheng T, Stevens RG, Leaderer D, Zhang Y, et al. CLOCK in breast tumorigenesis: genetic, epigenetic, and transcriptional profiling analyses. Cancer Res. 2010;70:1459-68. http://dx.doi.org/10.1158/0008-5472. CAN-09-3798.

35. Rabstein S, Bruning T, Harth V, Fischer HP, Haas S, Weiss $\mathrm{T}$, et al. N-acetyltransferase 2, exposure to aromatic and heterocyclic amines, and receptor-defined breast cancer. Eur J Cancer Prev. 2010;19:100-9. http://dx.doi.org/10.1097/ CEJ.0b013e328333fbb7.

36. Althuis MD, Fergenbaum JH, Garcia-Closas M, Brinton LA, Madigan MP, Sherman ME. Etiology of hormone receptordefined breast cancer: a systematic review of the literature. Cancer Epidemiol Biomarkers Prev. 2004;13:1558-68.

Received for publication: 8 November 2012 